\title{
Planning forest recreation: environmental economic instruments and the public participation
}

\author{
F. Oliveira ${ }^{1,2}$, P. Pintassilgo ${ }^{3}$, I. Mendes $^{4} \&$ J. A. Silva ${ }^{3}$ \\ ${ }^{1}$ School of Tourism and Maritime Technology, \\ Polytechnic Institute of Leiria, Portugal \\ ${ }^{2}$ Research Centre for Identity(ies) and Diversity(ies) - CIID, Portugal \\ ${ }^{3}$ Economics Faculty, University of Algarve, Portugal \\ ${ }^{4}$ ISEG (School of Economics and Management), \\ SOCIUS (Research Center in Economic and Organisational Sociology), \\ Technical University of Lisbon, Portugal
}

\begin{abstract}
In Portugal there is a growing demand for natural areas that provide a wide range of outdoor recreation. This paper focuses on the particular case of the Mata Nacional de Leiria (Leiria National Forest). This is a pine tree forest with 11,000 hectares and eight centuries of history. It has always been a public forest with open access to everyone, a fact that contributes to different kinds of use and benefits (walking, cycling, picnics, collecting firewood, fruits and berries, and other recreation activities). The proximity to a major urban and industrial centre, on one hand, and to a very popular beach coast, on the other, makes this a resource that is widely used by both residents and visitors.

In the future there is the possibility of implementing a set of actions to improve forest amenities and recreation, and later the emergence of environmental tourism activities and equipment. In this context, we want to know the economic valuation that actual users attach to these recreation improvements, but also realize their preferences and opinions regarding this project.

For this purpose we designed, tested and applied a double bounded dichotomous choice contingent valuation questionnaire. The results presented in this paper focus on responses to attitudinal and follow-up questions. More than
\end{abstract}


$70 \%$ of respondents have positively assessed the proposed improvements to the study area and about $40 \%$ enhanced their personal opinion on the type of interventions that they consider most appropriate. Answers focus the priority areas of intervention in the Mata Nacional de Leiria, the main concerns in its development, the type of actions that should (and should not) be implemented, respondents willingness to actively take part and, also, what the public authorities' role should be. At this stage, where Mata Nacional de Leiria is being considered in terms of future recreation and tourism offers, the results obtained provide important contributions and enhance the contingent valuation survey as a tool to support recreation planning, promoting public participation and the political decision-making process.

Keywords: forest recreation, contingent valuation, recreation planning, public participation, public preferences, willingness-to-pay.

\section{Introduction}

In Portugal, natural spaces - including forests - are increasingly sought for people to spend their free time. Aside from the usual services provided by the forests - ecological, biophysical, patrimonial and productive - the services related to recreation and tourism have become increasingly important (Figure 1).

In effect, due to the environmental and landscape aspects that characterize them, be it because of the fauna and flora that they contain or the activities and experiences that they provide, the forest spaces are ever more sought either for daily, informal, recreational moments or for more organized activities set in touristic experiences.

This reality is marked by two strategic recommendations in terms of communitarian politics. From the forest's perspective, it is a priority - in terms of competitiveness and efficiency - to develop the multifunctional character of the forests. In the area of recreation, the creation and potentiating of activities and infrastructures, especially in natural spaces, should be carefully planned in

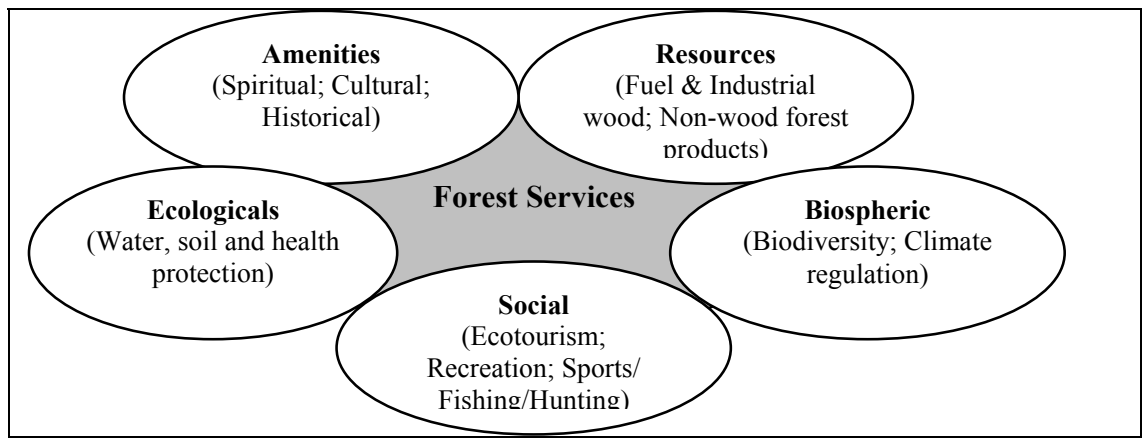

Figure 1: Forest services (millennium assessment [1]). 
order to obtain a continuous and balanced development without degrading the intrinsic characteristics of that space and, consequently, without affecting the quality of its uses and experiences in the future.

In relation to the first recommendation, according to the European Union Forest Action Plan [2], one of the key actions for the competitiveness of forests is to exchange and evaluate experiences in terms of valuation and trade of forest goods and services that are not wood based. The indication is to proceed to the quantification of the forests' global value and their functions, so as to create instruments to compensate the non-commercialized goods and services.

In turn, the second recommendation is part of the sustainable approach that should guide the current development of the overall economic and social activities, particularly those that directly use the natural resources. In this area, we find a vast sector that is associated to meeting the leisure needs of people, be it in an informal recreation's perspective or in the area of travel and tourism. In both cases, the search for experiences in natural contexts has grown, surpassing the average values verified in the other recreation and tourism offers (TIES) [3].

In this context, obtaining a sustainable pattern of occupation and use of natural spaces in terms of recreation and tourism goods and services depend on, among other aspects, making an integrated, participative and long term plan (COM (2007) 621 final) [4]. A plan which identifies the actual levels of environmental, social and economical tolerance of the locations; a participated plan that involves all the actors directly connected to the locations and resources to be developed and that considers their needs and preferences; a plan that identifies all the impacts - positive and negative - and that allows its internalization in the development process. In this area of the internalization of the impacts (strategic measure of the community policy for the environment [5], the environmental economics can contribute through the economic valuation methods of the benefits and environmental costs.

From the perspective of environmental economics, the development options such as recreation and tourism - affect the natural environments where they are implemented and may interfere with current activities and uses. Moreover, the changes verified in these environments have an economic dimension. In this context, regarding a particular development option, the environmental economy can estimate the total costs and benefits involved, including not only those with a market value but also those which, usually, are not translated into a monetary value. The total economic value obtained allows comparing the different development options.

Of the various methods used by environmental economics, the stated preferences methods are the most used for the valuation of goods and services in hypothetical markets or constructed markets (Pearce et al. [6]). Here, the individuals express their preferences towards the environment responding to hypothetical questions, through questionnaires and field or laboratory experiences. This study chose the contingent valuation method that uses surveys to infer about the reaction of individuals regarding a hypothetical situation of an alteration in the quality of an environmental resource or otherwise, to know how much they would be willing to pay to correct or avoid an environmental damage. 
In this case, we intend to study a forest space- the Mata Nacional de Leiria where there is the possibility of implementing a project to improve and diversify the recreation equipment and activities and, then, develop organized environmental tourism experiences. Thus, the main objective of this study focuses on, assessing the value that current users of the Mata allocate to these improvements and, taking advantage of the direct contact with the public, understanding what their views are in relation to this project. The aim is to gather enough information to support policy decisions and contribute to a participated planning.

\section{The survey: methodology issue}

\subsection{Object to be valued: background}

The Mata Nacional de Leiria is a public forest area located in the municipality of Marinha Grande, in the central coastal region of Portugal, which occupies approximately 11 thousand hectares (about 2/3 of the area of that municipality). It is a forest, mostly composed of pine trees, with over 700 years, internationally recognized for its antiquity and for the model of sustainable management that it develops.

Aside from its emblematic value, it is an important natural resource, with essential contributions on an economic, social and environmental level, for the region and the country. We highlight some, such as wood production, resin extraction, coastal protection, promotion of the quality of the air (in a region that is highly marked by industrialization), climate regulation, sustenance of habitats and biodiversity and the protection of water resources and of soil.

Additionally, the maintenance and preservation of this forest space provides a rich patrimony in terms of landscape, favourable to the development of a diversity of activities of informal recreation and with a high potential in the area of environmental tourism. In the last years, it is in the area of recreation that the Mata has obtained more supporters. To the users who live in the municipality and surrounding areas and that use it frequently, we add, particularly in the summer, the tourists that choose the beaches in the area for their holidays and that see in the Mata a complementary asset to their touristic experience.

Currently, we are living a moment of change with regards to municipal politics that directly involve that forest space. In effect, the importance of the Mata is notable in terms of the recreation experiences that it provides as well as the potential that may be used in this area. In this context, the National Forest Museum is being projected in partnership with three entities: the Marinha Grande Town Hall, the National Forest Authority (through the Unit of Forest Management of the Beira Litoral) along with the Ministry of Culture (through the Portuguese Institute of Museums). This project has a museum component, centred on the recuperation of patrimony belonging to the Forest Services (creation of the Museum in the Parque do Engenho, the Centre of environmental Interpretation within the old Pedreanes sawmill space) and an interpretation and environmental animation component to be developed in the Mata. In this area, it 
is intended to improve and increase the recreation offers and create facilities that promote a vaster and more diversified use in the Mata. This exogenous component foresees the approval of walking trails, the creation of more bicycle paths / foot paths, the implementation of a system of information boards and signage adjusted to natural surroundings, the cleaning and preservation of some of the most important environmental points of the Mata, integrating them in a networked circuit. Complementary to these actions, an improvement is expected with regards to cleaning and surveillance of the recreation equipment proposed, of the Mata, and the creation of some parking areas.

\subsection{Survey design and application}

This research uses the application of a survey in the form of a questionnaire to estimate the recreation value (benefits) that the Mata Nacional de Leiria has among its users. In this case, we considered all the users of the recreation equipment of this forest space. The contingent valuation questionnaire selects the format of discreet option with follow-up (dichotomous choice with follow up) to estimate the willingness to pay (WTP) of the respondents, the format considered more efficient by some researchers (Verbič and Slabe-Erker [7]; Alberini et al. [8]; Hanemann et al. [9]).

The questionnaire follows the usual structure of contingent valuation studies, beginning with an introductory approach of the study and three sections of questions (Bateman et al.) [10]. The first is a section that intends to identify the type of use of the environmental goods in study, characterize the recreation experiences that they provide and the attitudes and opinions of the respondents with regards to the environmental goods (in contexts of public participation, development strategies or preservation).

Subsequently is the valuation section made up by the contingency scenario, by the question of WTP and the questions of follow-up. In this case, it is intended that the respondents present their willingness to pay for a set of interventions that will improve, directly or indirectly, the recreation offers in the Mata. These interventions, which are a part of the National Forest Museum project, are presented in a model with two columns of photographs. In the first column, there are images that show the current state of the Mata, and in the second column, there is a set of images containing the various recreation improvements that are intended to be implemented. It is also indicated that The creation and maintenance of this equipment (including their cleaning and vigilance, safety of the users and the creation of car parks) entails significant costs which cannot be assured by public entities alone.

As such and supposing that the Friends of the Wood Fund was created, managed by the National Forest Museum, in order to allow the creation of the referred recreational equipment and its maintenance, the people are questioned about whether they would be willing to contribute with a monthly payment to this fund. The initial bids are of 1,2 and $5 €$ and they were obtained in a pre-test phase (procedure followed by Mill et al. [11]; Jim and Chen [12]; Jenkins et al. [13]; Lee and Han [14]; Scarpa et al. [15]). 
The last section is intended to characterize the respondents, in socioeconomic terms, and ends with an open question through which the respondents may express their opinion with regards to the management of the Mata and how to improve it. The objective is to get the respondents to freely express their preferences and convictions in relation to the Mata and its future, equally contributing to the consolidation of results related to the valuation that is made of that forest space. The reaction to this question may contribute to indicate the type of respondent that characterizes the sample, in other words, if they are a user that is in favour of conservation or if they support the development of the Mata for recreation purposes or others, if they have a formed opinion concerning the current management of the Mata or if they simply do not have anything else to add. Additionally, the number and type of answers obtained may, still, be analysed in a perspective of public will to intervene and of their main concerns.

In terms of application, a face-to-face approach was used, with the support of a team of interviewers (made up of 5 graduates and one Master student in the area of tourism and coordinated by one of the researchers). All the elements of the team, aside from having some experience in this field of work, were properly prepared, particularly during the pre-test phase.

\section{Survey results}

The survey was applied between July and August 2009 to the users of the recreation spaces and equipment of the Mata (more specifically in the picnic areas and in the bicycle paths/foot paths). The 419 individuals that constitute the sample were approached during or after their recreation experience.

More than $75 \%$ of the respondents came from the two closest municipalities Marinha Grande and Leiria - and the majority (91.17\%) had already used the forest before. Of these, most use it for picnics $(32.28 \%)$ or to socialize with friends and family (15.79\%). The hikes are the respondents' main physical activity $(13.12 \%)$. In terms of physical activity of medium / high impact running and cycling - together account for $11.55 \%$ of preferences. For the simple enjoyment of the environment that we experience in the forest - including the options to rest, to enjoy nature and the landscape and to be alone - is the main option of $19.42 \%$. The remaining options - walking the dog, practising TT and collecting firewood - are the main activity for a small number of individuals, in total, $2.1 \%$.

In general, the experience of recreation that you have in the Mata is good $(57.76 \%)$ or very good $(31.26 \%)$. It is also a positive evaluation compared to other benefits of the Mata, such as quality of the air or simply its existence and possible use. These results may, partly, justify the fact that $76.36 \%$ of respondents have presented a positive value when confronted with the question: Thus, what is the maximum value that you would be willing to pay in order to contribute to the Friends of the Mata Fund? The average willingness to pay, per user, was thus $€ 2.68$ - excluding protest responses and counting the zero responses, i.e. WTP $=0$ (Hanley and Knight [16]; Nunes [17]; Kniivilä et al. [18]; Kwak et al. [19]). 
Table 1: Indications and contributions to improve the management of the $\operatorname{Mata}(\mathrm{N}=158)$.

\begin{tabular}{|c|c|c|}
\hline Category of Answers & $N$ & $\%$ \\
\hline Improve Cleanliness & 71 & 32,13 \\
Improve Access & 24 & 10,86 \\
Proposals for the creation of recreation equipment & 17 & 7,69 \\
Conservation and development intervention & 37 & 16,74 \\
Importance and relevance of the study & 13 & 5,88 \\
More adequate type of management & 9 & 4,07 \\
Intervene in the signage and information & 11 & 4,98 \\
Environmental awareness and education & 6 & 2,71 \\
Create equipment and support services & 24 & 10,86 \\
Risks associated to the development of the Mata & 9 & 4,07 \\
\hline
\end{tabular}

In relation to the last question - Would you like to add any important point that you may consider relevant for the good management of the Mata? - 158 individuals responded to this question and presented 221 indications related to the management of the Mata. Table 1 aggregates this information in 10 categories: improve cleanliness, improve access, create recreation offers, create equipment and support services, intervene in the signage and information, environmental awareness and education, importance and relevance of the study, type of management to follow in the Mata, development interventions, recommendations for the development of the Mata.

A large part of the indications focus on the need to improve the cleanliness of the Mata $(32,13 \%)$, including the cleaning of the bicycle paths, of the stream and the introduction of rubbish bins and recycle bins. Concerning the interventions for the development of the Mata $(16,74 \%)$ the main highlight is the need to potentiate the Mata as a space for inclusion which should be considered also to receive users with mobility impairments.

The need to improve the access and create more facilities and support services meet the same number of indications $(10,84 \%)$, followed by further indications to circumvent the lack of information boards and signage. With regards to the initiatives and recreation facilities, a wide range of offers is proposed, such as TT trails, bike rental, spaces for games and playgrounds and promotion of activities geared towards children and youth.

In view of the decisions that have to be taken regarding the future of the Mata, respondents left some contributions to be retained. Concerns are evident with the preservation and maintenance of the existing natural environment and with the negative impact that some projects might arise. This area is particularly marked by the concern for the risks that are implicit to the development of tourism, even if within more environmental forms. The alleged increase in visitors and user of the Mata and the consequences in terms of traffic, congestion of some places, the noise and air pollution and waste generation, are the most referred aspects. In addition, concerns are presented in terms of the type and size 
of the equipment to be created and the risk of distortion of some areas of the Mata.

In any event, many have appreciated the project and activities involved and praised the study and the approach that was being followed, especially with regards to dealing with the public.

From the standpoint of the management model of the Mata, the indications reinforce the idea that this is, and should remain the State's responsibility. However, some respondents argue that the management of the Mata could be more efficient if partnerships between the State and other public and/or private entities were developed.

\section{Conclusion}

This study is developed in a context in which the multifunctional use of forest spaces is recommended, emphasizing its social and cultural importance in the development of recreation and tourism offers and experiences. In addition, it is recommended that the use and exploitation of any natural resource - including the forests - be the most sustainable possible. For this purpose we must identify and include all costs and benefits of any use of natural property including those that are usually translated into a market value.

In the case of the Mata Nacional de Leiria, where we foresee a set of changes in order to increase the recreation offers, we used the contingent valuation method to estimate the value that the recreation users of the Mata Nacional de Leiria attribute to a set of recreation improvements that could be developed in the future. Additionally, we took advantage of the direct contact with the users of the Mata to record their opinions, preferences and concerns regarding the future of that space.

The study developed in Mata Nacional de Leiria, thus shows the importance of environmental economics, through the contingent valuation method for:

- $\quad$ The involvement of the population and others users of the Mata (nonresidents) at a time of expected changes for that space;

- $\quad$ The identification of the benefits of the Mata (particularly recreational) and the effects associated to the different options of management and development of the Mata;

- $\quad$ The calculation of the recreational value of the Mata;

- The identification of management and development options for the Mata that meet the preferences of its users.

In terms of research, this study highlights the contributions that the contingent valuation questionnaire can bring for the consistency and efficiency of the process of the recreational and tourism projects' planning and development. Besides estimating the economic value of recreational benefits of the Mata, this study brought together information that may be essential in the planning process, contributing to the definition of more efficient development strategies and to a more participatory political decision-making. 


\section{References}

[1] Millennium Assessment (2005). Millennium Ecosystem Assessment. Washington, DC: Island Press URL: www.milleniumassessment.org/ documents/ document.766.aspx.pdf

[2] COM (2006) 302 Final, de 15 de Junho de 2006, [não publicada no jornal oficial] - Comunicação da Comissão Europeia sobre um plano de acção da União Europeia para as florestas.

[3] TIES (2006). TIES Global Ecotourism Fact Sheet. Washington, DC: TIES. URL: www.ecotourism.org.

[4] $\operatorname{COM}(2007) 621$ final de 19 de Outubro de 2007 - Agenda para um Turismo Europeu Sustentável e Competitivo

[5] DECISÃO No. 1600/2002/CE do Parlamento Europeu e do Conselho, de 22 de Julho de 2002 - Estabelece o sexto programa comunitário de acção em matéria de Ambiente

[6] Pearce, D., Özdemiroglu, E. et al. (2002). Economic Valuation with Stated Preference Techniques - Summary Guide. London: Department for Transport Local Government Regions. URL: http://www. communities.gov.uk/documents/ corporate/pdf/146871

[7] Verbič, M. and Slabe-Erker, R. (2009). An econometric analysis of willingness-to-pay for sustainable development. A Case study of the Volčji Potok landscape area. Ecological Economics. 68: 1316-1328. URL: http://dx.doi.org/10.1016/j.ecolecon.2008.09.002

[8] Alberini, A., Kanninen, B. and Carson, R. (1997). Modeling Response Incentive Effects in Dichotomous Choice Contingent Valuation Data. Land Economics. Vol. 73 (3): 309-324. URL: http://www.jstor.org/ stable/3147170.

[9] Hanemann, W., Loomis, J., and Kanninen, B. (1991). Statistical efficiency of double-bounded dichotomous choice contingent valuation. American Journal Agriculture Economics. 73: 1255-1263.

[10] Bateman, I., Carson, R., Day, B., Hanemann, M., Hanley, N., Hett, T., Jones-Lee, M., Loomes, G., Mourato, S., Özdemiroglu, E., Pearce, D., Sugden, R. and Swanson, J. (2002). Economic Valuation with Stated Preference Techniques: A Manual. Cheltenham, UK: Edward Elgar, Ltd.

[11] Mill, G., van Rensburgb, T., Hynesc, S. and Dooleyb, C. (2007). Preferences for multiple use forest management in Ireland: Citizen and consumer perspectives. Ecological Economics. 60: 642-653. URL: http://dx.doi.org/10.1016/j.ecolecon. 2006.02.005.

[12] Jim, C. and Chen, W. (2006). Recreation-amenity use and contingent valuation of urban green spaces in Guangzhou, China. Landscape and Urban Planning. 75: 81-96. URL: http://dx.doi.org/10.1016/ j.landurbplan.2004.08.008.

[13] Jenkins, D. H., Sullivan, J., Amacher, G. S., Nicholas, N. S. and Reaves, D. W. (2002). Valuing high altitude spruce-fir forest improvements: importance of forest condition and recreation activity. Journal of Forest Economics. 8: 77-99. 
[14] Lee, C.-K. and Han, S.-Y. (2002). Estimating the use and preservation values of national parks' tourism resources using a contingent valuation method. Tourism Management. 23:531-540.

[15] Scarpa, R., Hutchinson, W., Chilton, S. and Buondiorno, J. (2000). Importance of forest attributes in the willingness to pay for recreation: a contingent valuation study of Irish forests. Forest Policy and Economics. 1: 315-329.

[16] Hanley, N. and Knight, J. (1992). Valuing the environment: recent UK experience and an application to Green Belt Land. Journal of Environmental Planning and Management. 35(2): 145 - 160. URL: http://dx.doi.org/10.1080/09640569208711916.

[17] Nunes, P. (2000). Contingente Valuation of the benefits of natural areas and its warmglow component. Netherlands: Faculteit Economische, Katholieke Universiteit Leuven. Nr. 133.

[18] Kniivilä, M., Ovaskainen, V. and Saastamoinen, O. (2002). Costs and benefits of forest conservation: regional and local comparisons in Eastern Finland. Journal of Forest Economics. 8: 131-150.

[19] Kwak, S.-J., Yoo, S.-H. and Han, S.-Y. (2003). Estimating the public's value for urban forest in the Seoul Metropolitan Area of Korea: A Contingent Valuation Study. Urban Studies. 40 (11): 2207-2221. URL: http://dx.doi.org /10.1080/ 0042098032000123259. 